\title{
Vaccine Opposal in People Over 60 Years of Age in Mardin/ Turkey-A Territory with Low Rate of Vaccination
}

\section{COVID-19’a Karşı Aşılanmanın Düşük Olduğu Mardin/Türkiye İlinde 60 Yaş Üzeri Kişilerde Aşı Tutumu}

\author{
DAlev Başaran', (B) Barış Çil2 \\ 'Mardin Training and Research Hospital, Department of Physical Therapy and Rehabilitation, Mardin, Turkey \\ ${ }^{2}$ Mardin Training and Research Hospital, Department of Chest Diseases, Mardin, Turkey
}

\begin{abstract}
Objective: One of the most important public health practices in the prevention of communicable diseases is vaccination. In this study, it was desired to evaluate the vaccination attitude of individuals over the age of 60 years in cities where the rate of vaccination against COVID-19 was low rate.

Material and Method: Our research was carried out by reaching 396 people over the age of 60 in MardinTurkey. A questionnaire including the positive and negative attitudes of the participants towards the vaccine was filled in by face to face interviews.

Results: We found that 110 (45.8\%) of the participants who have not beeninnoculated in the provinces where the study was conducted did not trust the vaccine. Again, it was seen that $128(53.3 \%)$ of those who did not get inoculated were illiterate and 68 (28.3\%) were primary school graduates. There were no university graduates in the group that did not receive the vaccine. When positive and negative attitudes were evaluated, it was seen that $64(16.2 \%)$ people strongly disagree with the positive attitude, I would like to be vaccinated at the first opportunity, and 48 (12.1\%) strongly disagree with the positive attitude, I think everyone should be vaccinated. When the positive attitude of I trust the studies about the vaccine was examined, it was seen that 108 (27.3\%) people gave the answer of strongly disagree. Again, it was seen that $53.3 \%$ of the participants who did not get vaccinated were illiterate and $28.3 \%$ were primary school graduates.

Conclusion: The high level of concern about vaccine safety needs to be addressed. Future introduction of the vaccine should address these concerns, and a properly and thoroughly tested vaccine will help win the public's trust. In addition, campaigns should be organized to target low-educational groups, and they should be informed, due to the increase in the fear of vaccination as the level of education decreases.
\end{abstract}

Keywords: COVID-19 vaccine, low vaccination, vaccine hesitancy
Öz

Amaç: Bulaşıcı hastalıkların önlenmesinde en önemli halk sağlığı uygulamalarından biri aşılamadır. Bu çalışmada COVID-19' a karşı aşılanmadın düşük olduğu şehirlerde 60 yaş üstü bireylerde aşı tutumu değerlendirilmek istendi.

Gereç ve Yöntem: Araştırmamız Mardin/Türkiye ilinde 60 yaş üstü 396 kişiye ulaşılarak yapıldı. Katılımcılara aşıya karşı olumlu ve olumsuz tutumlarını içeren bir anket yüzyüze sorularak dolduruldu.

Bulgular: Çalışmanın yapıldığı ilde aşı yaptırmayan katıımcıların 110 $(\% 45,8)^{\prime}$ unun aşıya güvenmediğini gördük. Yine aşı yaptırmayanların $128(\% 53,3)$ 'inin okur yazar olmadığı, 68 (\%28,3)'ininse ilkokul mezunu olduğu görüldü. Aşı yaptırmayan grupta üniversite mezunu yoktu. Olumlu ve olumsuz tutumlar değerlendirildiğinde ilk fırsatta aşı olmak isterim olumlu tutumuna $64(\% 16,2)$ kişinin kesinlikle katılmıyorum, bence herkes aşı olmalı olumlu tutumuna 48 (\%12,1) kişinin kesinlikle katılmıyorum cevabını verdiği görüldü. Aşı hakkında yapılan çalışmalara güveniyorum olumlu tutumu incelendiğinde $108(\% 27,3)$ kişinin kesinlikle katılmıyorum cevabını verdiği görüldü.

Sonuç: Aşı güvenliği konusundaki yüksek düzeyde endişenin giderilmesi gerekmektedir. Aşının gelecekteki tanıtımı bu endişeleri gidermeli ve düzgün ve kapsamlı bir şekilde test edilmiş bir aşı, halkın güvenini kazanmaya yardımcı olacaktır. Ek olarak eğitim seviyesi düştükçe aşı treddütünün artması nedeniyle düşük eğitim seviyeli kitleleri hedef alacak kampanyalar düzenlenmeli, bilgilendirilmeleri sağlanmalıdır.

Anahtar Kelimeler: COVID-19 aşısı, aşılanma düşüklüğü, aşı tereddütü 


\section{INTRODUCTION}

Coronavirus-19 (COVID-19) first appeared in Wuhan, China. [1] The clinical features of the disease range from simple flulike symptoms to severe acute respiratory syndrome. It has been reported that mild symptoms in $81 \%$ of patients due to COVID-19 infection, severe respiratory failure symptoms in 14\%, and septic shock and multi-organ dysfunction in addition to respiratory failure in $5 \%$ has been observed. ${ }^{[2]}$

Therefore, the development and administration of COVID-19 vaccines becomes crucial for the prevention and eradication of the disease. ${ }^{[3]}$ Vaccines are one of the most effective methods used in the prevention of infectious diseases from past to present. Since the use of vaccines, there have been anti-vaccine activistism events. The reasons for this have been shown to be religious perspectives, differences in political views, and insufficient information about the safety of the vaccine. ${ }^{[4]}$ Despite the great advances in vaccination in the past century, the re-emergence of vaccine-preventable diseases has also created distrust in the society against newly discovered vaccines. ${ }^{[5]}$

In this study, it was aimed to evaluate positive and negative attitudes towards vaccination in a province with a low vaccination rate.

\section{MATERIALS AND METHOD}

This study was conducted in 01.06.2021- 30.06.2021 June 2021 by contacting 396 patients over 60 years of age in a face to face interview. The study questionnaire was administered face-to-face with patients by a nurse in a family practice. Signed informed consent forms were obtained from all participants, and our study, which complies with the Principles of the Declaration of Helsinki, was approved by the ethics committee. (Dicle Universitiy Ethics committe Number: 309)

An internationally validated questionnaire was used in the study to assess participants' attitudes towards the COVID-19 vaccine. ${ }^{[6]}$ The volunteers included in the face-to-face survey study were first asked their demographic information; age, gender, educational background, occupation and COVID-19 experience; whether they had COVID-19 infection, whether they believed in the protection of the CoronaVac vaccine, orhave been inoculated with the I. and II. dose of CoronaVac vaccine. If their answer was no, then they were asked about the reason. In addition, the Attitudes Towards COVID-19 Vaccine Scale was applied. The Attitudes Towards COVID-19 Vaccine Scale has 9 items and has two sub-dimensions (positive and negative attitudes). This scale consists of 9 items in total, including 4 items for positive attitudes and 5 items for negative attitudes, and its validity and reliability have been established. ${ }^{[6]}$

As a positive attitude, the participants were presented with options such as 'I would like my family to have the vaccine to be developed/developed for this disease', 'I would like to have the vaccine to be developed/developed for this disease at the first opportunity', 'I think everyone should have the vaccine to be developed/developed for this disease', 'I trust the explanations made about the vaccine to be developed/ developed'.

As a negative attitude; 'the vaccine to be developed/ developed may cause transmission of the disease'. (I), 'I think that the vaccine to be developed/developed will/ will not have a protective effect'. (I), 'The vaccine to be developed/developed is dangerous.'(I), 'I think the efficacy of the vaccine to be developed/developed will not/have not been adequately tested.'(I)'I think I can survive the epidemic without a vaccine.'(I) options were presentation. I= Inverse substances.

The statements in the scale were evaluated as "Strongly disagree (1)", “Disagree (2)", “Undecided (3)", "Agree (4)", "Strongly agree (5)".Items in the negative attitude subdimensions were scored inversely. A value between 1-5 was obtained by dividing the total score obtained by summing the item scores in the scale sub-dimension by the number of items in that sub-dimension.

High scores obtained from the positive attitude subdimension indicate that the attitude towards the vaccine was positive. It was calculated after the items in the negative attitude sub-dimension have been reversed, and the high scores in this sub-dimension indicated that the negative attitude towards the vaccine was less.

Inverse items $1 \rightarrow 5 ; 2 \rightarrow 4 ; 3 \rightarrow 3 ; 4 \rightarrow 2$; It was encoded as $5 \rightarrow 1$. In order to increase the reliability of this study, the survey was conducted in areas of different socioeconomic levels.

Inclusion criteria:Individiuals over 60 years old, who did not have mental health, auditory or speech problems, and who voluntarily accepted to participate in the study.

Exclusion criteria: Being too old to answer the questions, having mental disorder, speech or hearing impairment, and refusing to participate in the study.

\section{Statistical Analysis}

Statistical Package for the Social Sciences (SPSS) program was utilized for data evaluation and statistical analysis. Chisquare test was used when comparing percentage data in descriptive statistics, data expressed as mean, standard deviation and count. In comparisons, values with $\mathrm{p}<0.05$ were considered statistically significant.

\section{RESULTS}

A total of 396 volunteers were enrolled in this research. Of the people who agreed to participate in the study, $44.4 \%$ $(n=176)$ were female and $55.6 \%(n=220)$ were male. As of the date of the survey, $60.6 \%(n=240)$ of the participants have not been vaccinated against COVID-19, and 39.4\% $(n=156)$ have been vaccinated. As of the date of the survey, $74.7 \%$ $(n=296)$ of the people who participated in our research did not have COVID-19 infection, while $25.3 \%(n=100)$ had 
COVID-19 infection. Of the participants, $44.4 \%(n=176)$ were illiterate, $34.3 \%(n=136)$ were primary school graduates, $7.1 \%(n=28)$ were secondary school graduates, $12.1 \%(n=48)$ were high school graduates, and $2 \%(n=8)$ of them were university graduates (Table 1).

Table 1. Descriptive demographic characteristics of the study population

\begin{tabular}{lcc}
\hline Gender & N & $\%$ \\
$\quad$ Female & 176 & $44.4 \%$ \\
$\quad$ Male & 220 & $55.6 \%$ \\
Age (years) & & \\
$\quad 60-64$ & 212 & $53.5 \%$ \\
$65-69$ & 140 & $35.4 \%$ \\
$70-75$ & 32 & $8 \%$ \\
$75<$ & 12 & $3 \%$ \\
Educational Status & & \\
$\quad$ Illiterate & 176 & $44.4 \%$ \\
$\quad$ Primary School & 136 & $34.3 \%$ \\
$\quad$ Secondary School & 28 & $7.1 \%$ \\
$\quad$ High School & 48 & $12.1 \%$ \\
$\quad$ University Graduates & 8 & $2 \%$ \\
Had COVID-19 Infection & & \\
$\quad$ Yes & 100 & $25.3 \%$ \\
$\quad$ No & 296 & $74.7 \%$ \\
Inoculated with COVID-19 vaccine & & $60.6 \%$ \\
$\quad$ Not inoculated & 240 & $39.4 \%$ \\
Inoculated & 156 & $100 \%$ \\
Total & 396 & \\
\hline
\end{tabular}

When we tried to analyze the reasons for not getting vaccinated, $75 \%(n=180)$ of the participants did not trust the vaccine, $2 \%(n=5)$ of the participants stated that they had relatives who had COVID-19 after vaccination (Table $\mathbf{2}$ ).

Table 2. Reasons for not being inoculated

\begin{tabular}{lcc} 
& N & $\%$ \\
\hline Reasons for not being inoculated & & \\
Does not trust vaccine & 180 & $75 \%$ \\
Presence of relatives who had COVID-19 after inoculation & 5 & $2 \%$ \\
Has been infected with COVID-19 previously & 11 & $4.5 \%$ \\
Believing that vaccine could cause other diseases & 11 & $4.5 \%$ \\
Other & 33 & $13.7 \%$ \\
Toplam & 240 & $100 \%$ \\
\hline
\end{tabular}

It was shown that $53.3 \%$ of the participants who did not get vaccinated were illiterate, $28.3 \%$ were primary school graduates, $5 \%$ were secondary school graduates, and $13.3 \%$ were high school graduates. On the other hand $5.1 \%$ of the participants who had the vaccine were university graduates and $30.8 \%$ were illiterate. There was no university graduate who has not been vaccinated (Table $\mathbf{3}$ ).
Table 3. The educational status of the participants who refused to get vaccinated

\begin{tabular}{lccc}
\multirow{2}{*}{$\begin{array}{l}\text { Educational } \\
\text { Status }\end{array}$} & \multicolumn{2}{c}{ Vaccination Status } & \multirow{2}{*}{ Total } \\
\cline { 2 - 3 } & Not vaccinated N(\%) & Vaccinated N(\%) & \\
\hline Illiterate & $128(53.3 \%)$ & $48(30.8 \%)$ & 176 \\
Primary School & $68(28.3 \%)$ & $68(43.6 \%)$ & 136 \\
Secondary School & $12(5.0 \%)$ & $16(10.3 \%)$ & 28 \\
High School & $32(13.3 \%)$ & $16(10.3 \%)$ & 48 \\
University & $0(0 \%)$ & $8(5.1 \%)$ & 8 \\
Total & 240 & 156 & 396 \\
\hline
\end{tabular}

When the responses of the participants to the positive attitudes were examined; it was seen that 64 (16.2\%) people strongly disagree, 40 (10.1\%) disagree, and 44 (11.1\%) undecided. The phrase: 'I think everyone should be vaccinated', 48 (12.1\%) people strongly disagree, $44(11.1 \%)$ disagree, $68(17.2 \%)$ people were undecided. When the positive attitude of 'I trust the studies about the vaccine'was examined, it was seen that $108(27.3 \%)$ people strongly disagree, $68(17.2 \%)$ disagree, 68 (17.2\%) people were undecided.

When the responses of the participants to the negative attitudes were examined; 'I do not believe that the vaccine is protective', 148 (37.7\%)'people strongly agree', 64 (16.16\%)'agree', 104 (26.26\%) people answered 'undecided'. I strongly agree, 64 (16.16\%) people agree, 100 (25.25\%) said'I am undecided', 'I think I overcome the disease without vaccination', 64 (16.16\%) strongly agree, 20 (5.05\%)and it was observed that 136 (34.34\%) respondents gave the answer "I agree" and "I am undecided" (Table 4).

\section{DISCUSSION}

The current study has important implications. We found that $110(45.8 \%)$ of the participants who were not inoculated did not trust the vaccine. It was also determined that 128 (53.3\%) of those who did not get vaccinated were illiterate and $68(28.3 \%)$ were primary school graduates. There were no university graduates in the group that did not receive the vaccine.

When positive and negative attitudes were evaluated, 'I would like to be inoculated in the first possible opportunity' phrase has been interpreted as: $64(16.2 \%)$ people strongly disagree, 40 (10.1\%) disagree, and $44(11.1 \%)$ undecided. 'I think everyone should be vaccinated', 48 (12.1\%) people strongly disagree, $44(11.1 \%)$ disagree, 68 (17.2\%) people are undecided. When the positive attitude of 'I trust the studies about the vaccine'was examined, it was seen that $108(27.3 \%)$ people strongly disagree, 68 (17.2\%) disagree, 68 (17.2\%)were undecided.

When the responses of the participants to the negative attitudes were examined; It was seen that 'I do not believe in the protective effects of vaccine' 148 (37.7\%) people strongly agree, 64 (16.16) agree, and 104 (26.26\%) undecided. It was observed that $172(43.43 \%)$ people strongly agree, 64 (16.16\%) agree, and 100 (25.25\%)were undecided about the 


\begin{tabular}{|c|c|c|c|c|c|c|c|}
\hline \multirow{2}{*}{ POSITIVE ATTRIBUTE } & \multicolumn{2}{|c|}{ Gender } & \multirow{2}{*}{ Total } & \multirow{2}{*}{ INVERSE ATTRIBUTE } & \multicolumn{2}{|c|}{ Gender } & \multirow{2}{*}{ Total } \\
\hline & Female & Male & & & Female & Male & \\
\hline \multicolumn{4}{|c|}{ I want my family members to be inoculated. } & \multicolumn{4}{|c|}{ I do not believe in the protective effects of vaccine } \\
\hline Strongly disagree & $16(9.1 \%)$ & $32(14.5 \%)$ & $48(12.1 \%)$ & Strongly Agree & $80(20.2 \%)$ & $68(17.17 \%)$ & $148(37.37 \%)$ \\
\hline Disagree & $28(15.9 \%)$ & $12(5.5 \%)$ & $40(10.1 \%)$ & Agree & $32(8.08 \%)$ & $32(8.08 \%)$ & $64(16.16 \%)$ \\
\hline Undecided & $28(15.9 \%)$ & $32(14.5 \%)$ & $60(15.2 \%)$ & Undecided & $32(8.08 \%)$ & $72(18.18 \%)$ & $104(26.26 \%)$ \\
\hline Agree & $32(18.2 \%)$ & $44(20.0 \%)$ & $76(19.2 \%)$ & Disagree & $8(2.02 \%)$ & $24(6.06 \%)$ & $32(8.08 \%)$ \\
\hline Strongly Agree & $72(40.9 \%)$ & $100(45.5 \%)$ & $172(43.4 \%)$ & Strongly Disagree & $24(6.06 \%)$ & $24(6.06 \%)$ & $48(12.12 \%)$ \\
\hline \multicolumn{4}{|c|}{ I would like to be inoculated in the first possible opportunity. } & \multicolumn{4}{|c|}{ Vaccination may cause the spreading of the virus } \\
\hline Strongly disagree & $24(13.6 \%)$ & $40(18.2 \%)$ & $64(16.2 \%)$ & Strongly Agree & $84(21.21 \%)$ & $72(18.18 \%)$ & $156(39.39 \%)$ \\
\hline Disagree & $24(13.6 \%)$ & $16(7.3 \%)$ & $40(10.1 \%)$ & Agree & $20(5.05 \%)$ & $32(8.08 \%)$ & $52(13.13 \%)$ \\
\hline Undecided & $24(13.6 \%)$ & $20(9.1 \%)$ & $44(11.1 \%)$ & Undecided & $52(13.13 \%)$ & $80(20,20 \%)$ & $132(33.33 \%)$ \\
\hline Agree & $20(11.4 \%)$ & $44(20.0 \%)$ & $64(16.2 \%)$ & Disagree & $12(3.03 \%)$ & $16(4.04 \%)$ & $28(7.07 \%)$ \\
\hline Strongly Agree & $84(47.7 \%)$ & $100(45.5 \%)$ & $184(46.5 \%)$ & Strongly Disagree & $8(2.02 \%)$ & $20(5.05 \%)$ & $28(7.07 \%)$ \\
\hline \multicolumn{4}{|c|}{ Everynone should be inoculated } & Strongly Agree & $72(18.18 \%)$ & $100(25.25 \%)$ & $172(43.43 \%)$ \\
\hline Strongly disagree & $16(9.1 \%)$ & $32(14.5 \%)$ & $48(12.1 \%)$ & Agree & $28(7.07 \%)$ & $36(9.09 \%)$ & $64(16.16 \%)$ \\
\hline Disagree & $24(13.6 \%)$ & $20(9.1 \%)$ & $44(11.1 \%)$ & Undecided & $48(12.12 \%)$ & $52(13.13 \%)$ & $100(25.25 \%)$ \\
\hline Undecided & $36(20.5 \%)$ & $32(14.5 \%)$ & $68(17.2 \%)$ & Disagree & $8(2.02 \%)$ & $12(3.03 \%)$ & $20(5.05 \%)$ \\
\hline Agree & $16(9.1 \%)$ & $32(14.5 \%)$ & $48(12.1 \%)$ & Strongly Disagree & $20(5.05 \%)$ & $20(5.05 \%)$ & $40(10.10 \%)$ \\
\hline Strongly Agree & $84(47.7 \%)$ & $104(47.3 \%)$ & $188(47.5 \%)$ & \multicolumn{4}{|c|}{ Thinks that the vaccine has not been tested sufficiently } \\
\hline \multicolumn{4}{|c|}{ I trust the explanations \& briefings on vaccination } & Strongly Agree & $32(8.08 \%)$ & $36(9.09 \%)$ & $68(17.17 \%)$ \\
\hline Strongly disagree & $48(27.3 \%)$ & $60(27.3 \%)$ & $108(27.3 \%)$ & Agree & $32(8.08 \%)$ & $28(7.07 \%)$ & $60(15.15 \%)$ \\
\hline Disagree & $40(22.7 \%)$ & $28(12.7 \%)$ & $68(17.2 \%)$ & Undecided & $64(16.16 \%)$ & $96(24.24 \%)$ & $160(40.40 \%)$ \\
\hline Undecided & $24(13.6 \%)$ & 44 (20.0\%) & $68(17.2 \%)$ & Disagree & $28(7.07 \%)$ & $28(7.07 \%)$ & $56(14.14 \%)$ \\
\hline Agree & $4(2.3 \%)$ & 24 (10.9\%) & $28(7.1 \%)$ & Strongly Disagree & $20(5.05 \%)$ & $32(8.08 \%)$ & $52(13.13 \%)$ \\
\hline \multirow[t]{6}{*}{ Strongly Agree } & $60(34.1 \%)$ & $64(29.1 \%)$ & $124(31.3 \%)$ & \multicolumn{4}{|c|}{ I can overcome COVID-19 disease without getting vaccinated } \\
\hline & & & & Strongly Agree & $44(11.11 \%)$ & $20(5.05 \%)$ & $64(16.16 \%)$ \\
\hline & & & & Agree & $4(1.01 \%)$ & $16(4.04 \%)$ & $20(5.05 \%)$ \\
\hline & & & & Undecided & $56(14.14 \%)$ & $80(20.20 \%)$ & $136(34.34 \%)$ \\
\hline & & & & Disagree & $28(7.07 \%)$ & $68(17.17 \%)$ & $96(24.24 \%)$ \\
\hline & & & & Strongly Disagree & $44(11.11 \%)$ & $36(9.09 \%)$ & $80(20.20 \%)$ \\
\hline
\end{tabular}

negative attitude that'the vaccine is dangerous'. It was seen that $64(16.16 \%)$ people strongly agree, 20 (5.05\%) agree, and 136 (34.34\%)were undecided with the negative attitude of "I think I can overcome the disease without vaccination."

It has been reported that vaccine rejection and hesitations have increased in recent years. ${ }^{[7]}$ This increased vaccine rejection and hesitation can eventually lead to a reduction in vaccine coverage and affect its efficacy. ${ }^{[8-10]}$ Vaccine hesitancy is also listed among the top ten global health threats by the World Health Organization (WHO). ${ }^{[7]}$ Therefore, there is a need to determine the willingness of communities to accept the COVID-19 vaccine.

As technology develops, misinformation through the internet and media has led to an increase in anti-vaccine opinions. Clear and concise evidence-based communication to a broad audience will be crucial in the fight against antivaccination opposals. ${ }^{[4]}$ In the light of the COVID-19 outbreak, anti-vaccine sentiments are rising and anti-vaccine activists are increasing on social media. ${ }^{[5]}$

Research in China found that although more than $90 \%$ of respondents indicated they would accept the COVID-19 vaccine when available, almost $50 \%$ of these people would like to delay vaccination until the vaccine is confirmed to be safe. ${ }^{[1]}$ In a study conducted in Canada, the acceptance rate of the COVID-19 vaccine was found to be low. In this study, as the main factors in not accepting the vaccinehas been stated that vaccination has risks, safety and side effect concerns. ${ }^{[12]}$ Most of the survey studies among the general population classified by country showed a level of $\geq 70 \%$ acceptance about the COVID-19 vaccine. Low COVID-19 vaccine acceptance rates have been reported in the Middle East, Russia, Africa and several European countries. ${ }^{[13]}$

In an Italian study, uncertainty about the rapid development of COVID-19 vaccines was found to be the second most common reason for "No" or "Not sure" responses to vaccine intent, given the high rate of hesitation attributed to low trust in pharmaceutical companies. These concerns appear to be specific to new COVID-19 vaccines, and lower levels of anti-influenza vaccine opposition have been reported for 2020-2021. ${ }^{[14]}$ In our study, the rate of women who strongly agree with the item "I absolutely do not believe in the protection of the vaccine" was $13.6 \%$, while the rate of men was found to be $10.9 \%$ less. In our study, the rate of absolutely not believing in the protection of the vaccine was much higher (37.7\%). 
In a study conducted within the scope of Istanbul Medeniyet University Social Structure Research Program (TYAP) in Turkey, information was obtained about the society's approaches to vaccines. According to this study, the rate of those who want to be vaccinated immediately was $16.5 \%$, the rate of those who want to be vaccinated after the effectiveness of the vaccine has been proven, $26 \%$, the rate of those who will make their decision according to the type of vaccine to be made, $8.4 \%$, the rate of those who have never thought of being vaccinated was $24.6 \%$ and they are undecided about getting vaccinated. The rate of those who did was determined as $24.6 \%$. $^{[15]}$ In our study, the rate of those who answered "I strongly disagree" with the item "I want to be vaccinated at the first opportunity" was $16.2 \%$, while the rate of those who answered "I strongly agree" with this item was found to be $46.5 \%$.

According to results from surveys of COVID-19 vaccine acceptance rates from 33 different countries, the highest COVID-19 vaccine acceptance rates among adults were Ecuador (97.0\%), Malaysia (94.3\%), Indonesia (93.3\%) and China (91.3\%). However, the lowest COVID-19 vaccine acceptance rates were Kuwait (23.6\%), Jordan (28.4\%), Italy (53.7\%), Russia (54.9\%), Poland (56.3\%), USA (56.9\%) and France (58.9\%) (14).In our study, the rate of being vaccinated was $39.4 \%$. The data we have obtained lags behind most countries in the world.

As there are studies indicating that the level of education increases, the anti-vaccination increases. ${ }^{[16]}$ There are also studies stating that the level of anti-vaccination increases as the level of education decreases. ${ }^{[17]}$ In our study, it was seen that $128(53.3 \%)$ of those who did not get vaccinated were illiterate and $68(28.3 \%)$ were primary school graduates. There were no university graduates in the group that did not receive the vaccine.

Although the sample was selected in accordance with the exclusion criteria, some difficulties in communication can be counted among the limitations of the study due to the fact that the participating individuals were over the age of 60 years.

The high level of concern about vaccine safety needs to be addressed. Future introduction of the vaccine should address these concerns, and a properly and thoroughly tested vaccine will help to win the public's trust. In addition, campaigns should be organized to target low-educational groups, and they should be informed, due to the increase in the fear of vaccination as the level of education decreases. We believe it is important and more effective to begin promotion, begin policy making, and establish priority guidelines for vaccination before vaccines are approved. More quantitative and qualitative studies can be conducted to track individuals' vaccination acceptance and reasons at different time points.

Healthcare professionals will always play an important role in this struggle, as they will continue to be both a high-risk population and the first resource for patients. We hope our data can help governments, public health professionals and legislators achieve their goals in the COVID-19 vaccine campaign.

\section{ETHICAL DECLARATIONS}

Ethics Committee Approval: This study was approved by the ethics committee. (Dicle Universitiy Ethics committe Number: 309)

Informed Consent: All patients signed the free and informed consent form.

Referee Evaluation Process: Externally peer-reviewed.

Conflict of Interest Statement: The authors have no conflicts of interest to declare.

Financial Disclosure: The authors declared that this study has received no financial support.

Author Contributions: All of the authors declare that they have all participated in the design, execution, and analysis of the paper, and that they have approved the final version.

\section{REFERENCES}

1. Kabak M, Çil B, Hocanlı I. Relationship between leukocyte, neutrophil, lymphocyte, platelet counts, and neutrophil to lymphocyte ratio and polymerase chain reaction positivity. Int Immunopharmacol. 2021;93:107390.

2. B Çil, M Kabak.The Possible Factors That Affect The Clinical Severity And Mortality Of Covid Pneumonia. Acta Medica Mediterranea 2020;36:3655.

3. Qiang Gao, Linlin Bao, Haiyan Mao, Lin Wang et al. Development of an inactivated vaccine candidate for SARS-CoV-2. Science 2020;369:77-81.

4. Rafael Prieto Curiel, Humberto González Ramírez. Vaccination Strategies Against Covid 19 And The Difusion Of Anti Vaccination Views. Sci Rep. 2021;11:6626.

5. Puri N, Coomes EA, Haghbayan H, Gunaratne K. Social media and vaccine hesitancy: new updates for the era of COVID-19 and globalized infectious diseases. Hum Vaccin Immunother 2020;16(11):2586-93.

6. Geniş B, Gürhan N, Koç M, et al. Development of Perception and Attitude Scales Associated with the COVID-19 Pandemic (2020).

7. Brit Trogen, David Oshinsky, Arthur Caplan. Adverse Consequences of Rushing a SARS-CoV-2 Vaccine:Implications for Public Trust. JAMA 2020;323:2460-1.

8. Jarrett C, Wilson R, O'Leary M, Eckersberger E, Larson HJ. The SAGE Working Group on Vaccine Hesitancy. Strategies for addressing vaccine hesitancy-A systematic review. Vaccine 2015;33:4180-90.

9. Sadaf A, Richards J.L, Glanz J, Salmon D.A, Omer SB. A systematic review of interventions for reducing parental vaccine refusal and vaccine hesitancy. Vaccine 2013;31:4293-304.

10. Larson H.J, Jarrett C, Eckersberger E, Smith D.M, Paterson P. Understanding vaccine hesitancy around vaccines and vaccination from a global perspective:A systematic review of published literature, 2007-2012. Vaccine 2014;32:2150-9.

11. Wang J, Jing R, Lai X, et al. Acceptance of COVID-19 Vaccination during the COVID-19 Pandemic in China. Vaccines (Basel). 2020;8(3):482.

12. Frank, K.;Arim, R. Canadians' Willingness to Get a COVID-19 Vaccine:Group Differences and Reasons for Vaccine Hesitancy 2020. Available online:https://www150.statcan.gc.ca/n1/pub/45-28-0001/2020001/ article/00073-eng.htm(accessed on 12 November 2020).

13. Sallam M. COVID-19 Vaccine Hesitancy Worldwide:A Concise Systematic Review of Vaccine Acceptance Rates. Vaccines (Basel). 2021;9(2):160.

14. Francesco Di Gennaro, Rita Murri, Francesco Vladimiro Segala et al., Attitudes towards Anti-SARS-CoV2 Vaccination among Healthcare Workers:Results from a National Survey in Italy. Viruses. 2021;13(3):371.

15. Karadeniz Teknik Üniversitesi-Stratejik Araştırma MerkeziProtokol Dergisi |Yıl 2 | Sayı 1 www.ktu.edu.tr/sam 2021.

16. Paulina Pisaniak, Aleksander Tarczon, Milena Konarskaet al.,Parents Opinions and Knowledge About Vaccination in Poland-A Cross-Sectional Observational StudyInt J Gen Med. 2021;14:3235-42.

17. Cadeddu C, Daugbjerg S, Ricciardi W, et al. Beliefs towards vaccination and trust in the scientific community in Italy. Vaccine 2020;38(42):6609-17. 